\title{
The impact of corruption on service delivery: a topical matter in the South African Municipalities
}

\author{
Mabeba SJ \\ University of Limpopo \\ Department of Public Administration
}

\section{Keywords}

Corruption, service delivery, municipalities, personal interests, South Africa.

\begin{abstract}
One of the topical challenges facing South African municipalities recently is corruption. From time-to-time citizens learn about and witness the corrupt practices of public officials in the Local Government sphere. Arguably, the phenomenon of corruption has both direct and indirect impact on service delivery with specific focus to municipalities. Section 152(1) of the Constitution of the Republic of South Africa (1996) states that the Local Government sphere has the mandate to ensure the provision of services to communities in a sustainable manner. Subsequently, some of the communities across the country still wish to have access to basic services namely: water, electricity, community halls and proper tar roads to name a few. As a result, at times it seems impossible for municipalities to smoothly render such services due to corrupt practices emanating in the South African Local Government sphere. This article aimed to explore the impact of corruption on service delivery in the South African municipalities. The article fully relied on secondary data as it collects information from newspapers, books, journal articles, conference proceedings, officials report and academic dissertations. In pursuit of all this, Afrocentricity: a theory of social change has been placed in context with a view that the needs of the society should be placed at the center of the local government sphere. To be specific, these needs are but not limited to water and electricity. Looking at the findings of the study, indeed literature can confirm that corruptions have negative impact on the ability of the municipalities in South Africa to provide basic services. Because the interests of the public are competing with those of the municipal officials. Therefore, at the end of the day service delivery is compromised due unlawful practices.
\end{abstract}

\section{Introduction}

Corruption has become an inevitable concern for citizens, academics, opposition parties and possibly the ruling party. This is so as unethical practices (corrupt practices) within South African municipalities are reported from time to time in the media space. As such, these practices affect the delivery of services (housing, water, electricity, and waste removal) to constituents. Service delivery has become a tormenting issue in South Africa (Raophala, 2013). To a certain extent, the rendering of services to community members in an effective and efficient manner becomes slightly impossible due to corruption rooted in the Local Government sphere. According to the former President of the Republic of South Africa (Mbeki, 2000:15), South Africa still has households living under poverty conditions and improper infrastructure, regardless of Section 195 (1) of the Constitution of the Republic of South Africa 1996 emphasising that citizens needs must be responded to. At the same time, the practice of corruption is a challenge for less developed nations in the sense that resources that are allocated to address socio-economic and developmental objectives are sometimes used by individuals in the local government sphere to benefit few individuals meanwhile neglecting the core functions of municipalities (Soliman \& Cable, 2011). As a result, members of the public and distinguished stakeholders are continuously concerned with corruption in the South African municipalities because it affects the livelihood of households including taxpayers by causing a decline in service delivery, neglecting economic growth and eroding the legitimacy and the functioning of the sphere of government that is closer to the constituents. In this context, this article seeks to explore the impact of corruption on service delivery using South African municipalities as point of reference. The section after this one will deliberate on the theoretical framework that the article is rooted on. 


\section{Afrocentricity: A theory of social change}

The argument of this paper is consolidated by the theory of afrocentricity. The use of this theory in the paper assists scholars, government and the society at large to understand that African countries should prioritise the interests of the public. This includes basic services. In his motto, Asante (2002) stated that "It is not enough to know, one must act to humanize the world". This is a clear example that he is emphasising for the centrality of African interests and perspectives in today's world. Afrocentricity: A Theory of Social Change, it was first made open to the public in 1980 and in 2003 it was revised, this theory came into existence in an attempt to guide states on how to become Afrocentric. This theory goes on to deliberate about the need for members of the public to run away from victimisation. The theory is indeed relevant as it makes the government to be conscious about the needs of the public. It raises consciousness about members of the public who are often neglected and victimised, particularly in African countries. Asante places the concept of Afrocentricity in context with a definition that states "a mode of thought and action, putting members of the public in African countries at the forefront. This scholar proceeds on to develop this definition more fully with a view of discussion of the theories and ideologies that form the basis of Afrocentric thought, a comparison of his revolution to other major social revolutions and means for individual achievement of Afrocentrism. Some of the arguments in this theory are the power in African countries to transform the lives of their constituents. Asante stresses the need to change attitudes, character, values, and behaviours to accomplish an informed consciousness that is centered around doing things in an African way while prioritising the needs of the society (Banks, 2004). It can however be stated that public officials in the South African municipalities should be conscious about service delivery implications that might arise as a result of unethical practices (corruption) from their institutions. Because members of the public end up being victimised with lack of service delivery due to unlawful practices such as corruption. If members of the public continue to be victims of poor service delivery, then municipalities should understand that it is their constituents who suffer the most at the end of the day. This article therefore concludes that municipalities should stop victimising members of the public with lack of services while officials are putting their personal interests at the forefront. Otherwise, it is through proper service delivery that the dignity of the society can be restored.

\section{Corruption in the context of local government}

The term of corruption can be described in different ways depending on the point of perception of different people (Mafunisa, 2007). In line with that, the concept of corruption can be described as an unethical practice that is not morally acceptable in the municipal environment. On the other hand, Pauw, Woods, Van der Linde, Fourie \& Visser (2009) suggested that the term can be explained as the abuse of position in the workplace to fulfil personal interests or interests of a particular group of individuals a municipal official is associated to. These scholars are of the opinion that corruption takes place in two ways that has to do with internal and external individuals who pursue unethical practices that weakens the municipality's social and economic responsibilities. De Graaf (2007) deliberated those corruptions in the public sector becomes visible when public officials sell government resources in an attempt to fulfil personal interests. A practical example, municipal officials sometimes collect bribes from prospective services providers (tenderprenuers as they sometimes refer to them as such) in exchange for favours and tenders. Porta (2012) viewed corruption differently, this scholar believes that corruption occurs in the form of favouritism, nepotism, clientelism, vote-buying, fraud and maladministration. Subsequently, practices of such nature weaken the ability of South African municipalities to provide sustainable services to communities smoothly. On the other hand, Faull (2007) claimed that for any act to be regarded as corruption it must have elements of abuse of power assigned to a municipal official for private gain. Nonetheless, in this context, corruption can be viewed further as an unlawful activity of awarding of tenders and jobs to immediate family members and misappropriation of municipal finances and assets for personal benefits (Kanyane, 2005; Mafunisa, 2007; Edwards, 2008; Ruhiiga, 2009). In an attempt to place the meaning of corruption in context, The Brazil Business (2012) contended that exchanging of benefits to authorities with a view of being given favours in the near future is also corruption. For instance, offering financial resources to a municipal official with a view of being awarded a tender in future is one of the practical examples of corruption. In view of all this, this article proceeds on to argue that corruption can take place in two ways, either directly or indirectly. For example, a tenderpreneur can voluntarily offer a 
gift either in the form of money or otherwise to a senior municipal official without the official being aware of the exact motive behind that offering. Therefore, at a large stage the giver might need a favour that might require the same official to eventually deviate from lawful ways of doing things in an attempt to return the favour to the same individual who once offered a gift to the official. On that note, this article argues that corruption can be defined in many ways depending on the context one uses to provide clarification on the concept itself.

\section{Unpacking the concept of service delivery}

At times members of the society witness service delivery protests that take place in various communities across the country. However, the aim of this section is not to dwell much on service delivery protests. This section seeks to provide clarification on the concept of service delivery. It is worth deliberating that before the article can attempt to unpack the impact of corruption on service delivery, it is of paramount importance to provide a clear understanding of what service delivery is and how does it look like. The paper goes on to pose an answer seeking question: What is service delivery in the context of local government? Secondly, does those who normally protest in relation to service delivery understand what the concept is all about? In an attempt to address these questions, service delivery refers to services rendered to citizens of a country by the local government sphere (Ardigó \& Chêne, 2017). Additionally, Canada (2002) stated that service delivery is the organizational and structural obligation of improving the municipality's performance through the rendering of basic services. These basic services include but not limited to water, electricity, waste management services, infrastructure, and shelter. In consistent with that, Section 26 and 27 of the Constitution of the Republic of South Africa 1996 justifies that everyone has the right to adequate housing and water as part of services that should be rendered by the local government sphere. Chen, Dean, Frank and Kumar (2014) added that service delivery is a common term in South Africa which is used to describe the provision of essential services which households cannot live without. These scholars proceed on to describe service delivery as an end user-based model that offers a reliable and readily accessible system. Moreover, service delivery is described as a situation where the beneficiary knows what to expect from the service provider, which is the municipality in this context. Over and above, it is equally important to understand that service delivery involves an integrated process of providing subsidised, charged and non-charged essential services to community members. On the other side, the term means availing basic services to community members (Johannison, 2007; Venter, 2010). It can then be acknowledged that service delivery in the context of local government is when South African municipalities fulfill their constitutional and legislative mandate by providing basic services to every individual who resides in South Africa. The section below will unpack the impact of corruption on service delivery.

\section{Corruption delays service delivery}

As it was stated elsewhere that this article is rooted on the exploration of the impact of corruption on service delivery in the South African municipalities. In line with that, there are many scholars who have deliberated on the topic under exploration. However, this article argues that as far as corruption is concerned in the local government sphere, it should be acknowledged that it has negative impact on the ability of municipalities to render services smoothly. As a result, service delivery is in one way or the other compromised due to personal interests of the municipal officials that emanate as and when essential services should be rendered to members of the public. In view of all this, Chene (2014) stated corruption impact service delivery in the sense that clientelism, patronage and bribery compromise the rights of citizens against equal access to municipal services while promoting inequalities that limit constituents' access to basic services. Consequently, the poor and voiceless residents end up being affected the most along the process. Oslo Governance Centre (2004) added that corruption can lead to a decline in the service delivery performance, as such this can prevent citizens from accessing basic services. Therefore, this causes inequality in the communities as the privileged ones can afford to pay for private services. Furthermore, Kroukamp (2006:207) stated that corruption is especially harmful in a developing country such as South Africa due to the fact that this country tends to have fewer resources and need to use these scarce resources in the most effective way as well as a lack of confidence in the government. Flowing from this perspective, Manyaka \& Nkuna (2014) argued that "the overall goal in the fight against corruption in the 
public sector is to improve service delivery. This can be achieved by bringing sustainable reduction in corrupt behaviour and improving good governance". This is a clear indication that corruption negatively impacts service delivery. Municipalities could save a lot of money by objectively fighting corruption in the local government sphere. Flowing from this argument, the Local government sphere losses a huge number of financial resources that are meant for various purposes including service delivery. According to Consumer Goods Council (2006), R50 Billion to R150 Billion is lost in South Africa on yearly basis because of unethical practices such as corruption. In pursuit to highlight the impact of corruption on service delivery, Makwetu (2019) the potential R1, 6 billion losses of investments made with VBS mutual Bank also crippled the financial reputation of the sixteen affected municipalities, and this had impact on the rendering of infrastructure and maintenance projects. The former Auditor-General used a project at Metsimaholo Local Municipality in Free State, where in a project to construct a R21,9 million sports complex, $99 \%$ of the money was utilised but there were no tangible structures to indicate that the project has indeed materialised. In line with the audit report from the Auditor-General, it can then be stated that corruption does exist in the South African municipalities and to a large extent it worsens the state of service delivery within communities.

Furthermore, Kaufmann (1997) acknowledged that corruption disadvantages economic development. This is so because resources that are meant for developmental initiatives in the society are often used for personal gains and interests. According to Madonsela (2010) it should be admitted that corruption is one of the contributing factors to slow development. This phenomenon causes, among others, poor service delivery, use of more resources while getting less output and excessive costs. This statement is seconded by Stapenhurst (2006) who wrote that corruption in the local government sphere disadvantages the poor as they fully rely on public services. Additionally, corruption exhausts financial resources that can be utilised for rendering of basic services. Corruption is a societal concern as it affects everyone whether rich or poor. In an attempt to emphasis this, it can be asserted that corruption mostly affects the poor as they continue to be vulnerable and victimised due to inaccessibility of services from their local municipalities. On that note, corruption weakens the ability of municipalities to uplift community members within the jurisdiction of their respective municipalities (Makhanya, 2014). Based on the reviewed literature, it can then be concluded that corruption negatively impact service delivery in many ways. However, this article concludes by emphasising that dealing with corruption should be the starting point of every municipality in South Africa with a view of prioritising the human rights of all community members. Therefore, service delivery should be at the center of each and every municipality.

\section{Research methodology}

The objective of this paper was achieved through extensive review of readily available (secondary) data that corresponds with the topic under exploration. This includes newspapers, journal articles, conference proceedings, academic books and government reports. The adoption of this research design was necessary with a view of establishing the extent to which corruption negatively impact service delivery, particularly in the South African municipalities.

\section{Conclusion and recommendations}

This paper explored the impact of corruption on service delivery with specific focus to South African municipalities. This was important for the researcher to establish the extent at which corruption negatively impact service delivery. Therefore, the goal of the study was successfully achieved. In light of this, the paper concludes by stating that while corruption has become a major concern in the South African local government sphere, it is important to highlight that this unlawful practice continues to have a huge impact on the ability of municipalities to provide services to members of the community in a sustainable manner. This is so because financial resources that are meant for service delivery are often used for personal interests. Therefore, this delays municipalities to provide essential services to community members and to a large extent beneficiaries continue to be victimised with lack of service delivery. It can therefore be concluded that municipal officials should at all times remember that it is the beneficiaries of public services who suffer the most as a result of unethical practices that are rooted in the municipalities. However, the core responsibility of municipalities is to provide basic services efficiently and effectively. Therefore, adequate service delivery can only be possible once the local government 
sphere is willing to deal harshly with those who do corruption at the expense of community members and taxpayers. Otherwise, corruption is one of the contributing factors to slow provision of services to community members.

\section{References}

Canada. (2002). Alternative Service Delivery Division. Communications Policy of the Government of Canada. Ottawa, [Online], Available from: (Accessed: 23 March 2021).

Chen, L, Dean J, Frank J and Kumar R. (2014). What does service delivery really mean? Columbia University. School of International Public affairs.

Chêne. M. (2014). The Impact of Corruption on Growth and Inequality. https://www.transparency.org/whatwedo/ answer/the_impact_of_corruption_on_growth_and_inequality.

Constitution of the Republic of South Africa. (1996). Pretoria: Government Printers.

Consumer Goods Council. (2006). May Bulletin, Johannesburg.

De Graaf, G. (2007). Causes of Corruption: Towards A Contextual Theory of Corruption. Public Administration Quarterly, 31(1/2): 39-86.

Edwards, T. (2008). The Nuts and Bolts of Ethics, Accountability and Professionalism in the Public Sector: An ethical leadership perspective. Journal of Public Administration, 43(3.1): 77-88.

Faull, A. (2011). Civilian Perceptions and Experiences of Corruption and the South African Police Service, ISS Paper 226. Pretoria: Institute for Security Studies, [Online], Available from: (Accessed: 5 January 2015).

Johannisson,B. 2007. Enacting local economic development - theoretical and methodological challenges. Journal of Enterprising Communities: People and Places in the Global Economy (2): 7-26. Accessed May 11, 2021. http://dx.doi.org/10.1108/17506200710736230.

Kanyane, M.H. (2005). Conflict of interest in South Africa: Unravelling the Revolving Door. Journal of Public Administration. Conference Proceedings, October 2005.

Kaufmann, D., Corruption: The facts. Foreign Policy 107, 114-131.

Madonsela, T.N. (2010). Corruption and governance challenges: The South African experience. National Conference on Corruption and Governance Challenges. Nigeria, 21 January 2010.

Mafunisa, M., J. (2007). Corruption and Service Delivery in the Public Service: The case of Limpopo Province. Journal of Public Administration. 42 (3): 260-270.

Makhanya, M.S. (2014). Welcome: UNISA/UNODC/PSC/ Commemoration of the 2014 International AntiCorruption Day. 9 December 2014.

Makwetu, T.K. (2019). Mail \& Guardian. http//: Billions lost in disorganised municipalities - The Mail \& Guardian (mg.co.za) accessed on $(28 / 03 / 2021)$

Manyaka, R.K and Nkuna N.W. (2014). The Phenomenon of Corruption in the South African Public Sector: Challenges and Opportunities. Mediterranean Journal of Social Sciences MCSER Publishing, Rome-Italy , 5 (27):1572-1580.

Mbeki, T. (2000). The integrated sustainable rural development strategy. Pretoria. Government Printers.

Pauw, J.C, Woods, G.,Van der Linde G.J.A., Fourie D and Visser C.B .(2009). Managing Public Money: Systems from the South: Johannesburg: Heinemann

Porta, D. (2012). The hidden order of corruption: An institutional approach. ASHGATE

Raophala, M.N. (2013). Master of Public Administration, mini dissertation "municipal service delivery in Greater Tzaneen local municipality in Limpopo Province, A case of Lenyenye Township". University of Limpopo.

Ruhiiga, T.M .(2009). Costing the impact of corruption on service delivery in South Africa: An exploratory overview. Journal of Public Administration, 44 (4): 1090 -1101.

Soliman, H and Cable, S. (2011). Sinking under the weight of corruption: Neoliberal reform, political accountability and justice. Current Sociology, 59(6):735-753.

Stapenhurst, R. (2006). The role of parliament in curbing corruption. Washington, DC: World Bank Institute.

UN Development Programme - Oslo Governance Centre. (2004). The Impact of Corruption on the Human Rights Based Approach to Development. $\mathrm{ma} /$ xmlui/bitstream/handle/123456789/30538/0284The_

Impact_of_Corruption_on_the_Human_Rights_Based_Approach_to_Development(2005)r.pdf?sequence=1

Venter, A. 2010. Government and politics in South Africa. Pretoria: Van Schaik. 